\title{
A Trophic Structure Model of the Douala-Edea Reserve Mangrove (Cameroon) with Consideration of Sustainable Utilization of its Resources
}

\author{
Longonje Simon ${ }^{1}$, Findi Emilien ${ }^{2}$ \\ ${ }^{1}$ Department of Environmental Science, University of Buea, P. O. Box 63 Buea, Cameroon \\ ${ }^{2}$ Department of Environmental Science, University of Buea, P. O. Box 63 Buea, Cameroon
}

\begin{abstract}
The Douala-Edea reserve mangrove is the largest mangrove area in a national park in Cameroon. It has an area of about $272.79 \mathrm{~km} 2$ (Findi, 2015) and is subjected to substantial anthropogenic impact through intensive harvest of mangrove wood and fishery. In order to integrate available information on biomass, catches, food spectrum and dynamics of the main species populations of the system, a trophic steady state model of 21 compartments was constructed using the ECOPATH II software (Christensen \& Pauly, 1992). About eighty percent of total system biomass is made up by mangroves (Rhizophora spp), which are assumed to cover about 65\% of the total area and contribute about $70 \%$ to the system's primary production. The remaining biomass is distributed between the pelagic and benthic domains in proportions of $10 \%$ and $90 \%$ respectively. Through litter fall, mangroves inject the main primary food source into the system, which is either consumed directly by herbivores (principally land crabs) or, when already metabolized by bacteria, by detritus (principally fiddler crabs, Uca spp.). According to the model estimates, energy flow through the fish and shrimp compartments is of relatively high importance for the energy cycling within the system, a finding which is similar to the situation in other mangrove estuaries reported in the literature. The dominance of mangrove epibenthos is attributed to the fact that a large part of the system's production remains within the mangrove forest as material export to the estuary is restricted to spring tides, when the forest is completely inundated. Total system throughput $\left(400.54 \mathrm{t} / \mathrm{km}^{2} /\right.$ year) and mean transfer efficiency between trophic levels (13.8\%) calculated by the model fit well into the range reported for other tropical coastal ecosystems. The very high gross efficiency of the fishery (catch/net primary production) of $17.4 \cdot 6 \%$ and its low trophic level $(2 \cdot 1)$ is explained by a high harvesting rate of mangroves and the fact that the main animal resource in the system are the mangrove crabs (Ucides cordatus), which feed at the first trophic level. The model was balanced assuming a turnover rate for the land crabs of $P / B=0.44$ (P/B: production per unit of biomass) which is possibly low and more realistic, suggesting a situation in which more biomass is being harvested than produced, which hints to an overexploitation of this resource $A$ ranking of the various system components in terms of their contribution to the system function (ascendency sensu Ulanowicz, 1997) revealed that detritus and associated bacteria contribute $27 \%$, mangroves $26 \%$, fiddler crabs and predatory crabs $13 \%$, phytoplankton and zooplankton 10\%, mangrove crabs 10\%, and the remaining 14 groups $14 \%$ to the total ascendency. Summary statistics of the model are given and compared with those of other coastal ecosystems.
\end{abstract}

Keywords: Biomass; ecosystem structure; tropical estuary; resource use; Cameroon

\section{Introduction}

The Douala-Edea Wildlife Reserve (DEWR) is located in the south western part of Cameroon, in the littoral region between Wouri and Senegal maritime administrative division within the kribi- Douala basin of the Atlantic Ocean (Figure 1). It lie between latitude $3^{\circ} 14^{\prime}$ and $3^{\circ} 53^{\prime}$ north and longitude $9^{\circ} 30^{\prime}$ and $10^{\circ} 05^{\prime}$ East. The study area $(160,000$ ha), stretches about $100 \mathrm{~km}$ along the Cameroon coastline (Figure 1). It's was established as a protected area in 1932 and designated as a wildlife park for scientific purposes in 1971.The local communities in and around the reserve are highly dependent on the mangroves for both subsistence and commercial uses ( Longonje, 2002; Nfotabong-Atheull et al., 2009). Therefore, mangroves are under severe pressure from anthropogenic activities and natural disaster.

The climate is equatorial type with four seasons, having a horizontal climatogramm due to the forest nature, monthly mean air temperature ranges from $24^{\circ} \mathrm{C}$ to $27^{\circ} \mathrm{C}$ to (CWCS, 1998). Annual precipitation amount to $3000-4000 \mathrm{~mm}$ (CWCS, 2008), the dry season spanning November to April, having October with highest rain fall with January being the driest period.
In the wet season, salinity decreases drastically in the mangrove (from about 15-20 to $<10$ (using the Practical Salinity Scale) in the central part of the study area (Din and Baltzer, 2008) less than $30 \mathrm{~km}$ away from the ocean.

A socioeconomic evaluation by Longonje (2002) revealed that there is a high degree of interaction between the local residents and the mangrove forest, resulting to significant level of dependency of the local communities on the mangrove resources. The framework of dependence include: fishing and mangrove wood extraction, $75 \%$ of the households of the villages in the study area economically depend on the mangrove system. Mangrove wood is used locally for house construction, fishing traps and as fire wood for fish smoking. The amount extracted annually is estimated as roughly $42839 \mathrm{~m}^{3}$ ( Feka et al 2009). Further mangrove products of local importance are fish species of the families Lutjanidae, Hepsetidae, Cichlidae, Polypteridae, Clupeidae, Ariidae, shrimps (Penaeus spp., Macrobrachium sp.), the mussels (Mytella sp.) and crabs (Callinectes sp.) ( Findi, 2015). Unfortunately, catch data are as yet unavailable for these fishery products from the study site The fact that mangrove products are utilised amongst commercial and subsistence users in the study area, has caused the significant degradation and ecological impact on the mangrove ecosystem. 


\section{International Journal of Science and Research (IJSR) \\ ISSN (Online): 2319-7064 \\ Index Copernicus Value (2013): 6.14 | Impact Factor (2015): 6.391}

The aim of the present study was to obtain a holistic picture of the Douala-Edea mangrove ecosystem by (a) identifying the main functional groups of the system (species or guilds including harvested resources); (b) quantifying their respective stock sizes, productivities and harvest rates and (c) tracing and quantifying the biomass flows through the system. We thus constructed a first steady-state-model of trophic flows of the system. As input data, available information from literature was used. For those system compartments, for which essential data are still lacking, additional information was taken from reported studies on other mangrove systems.

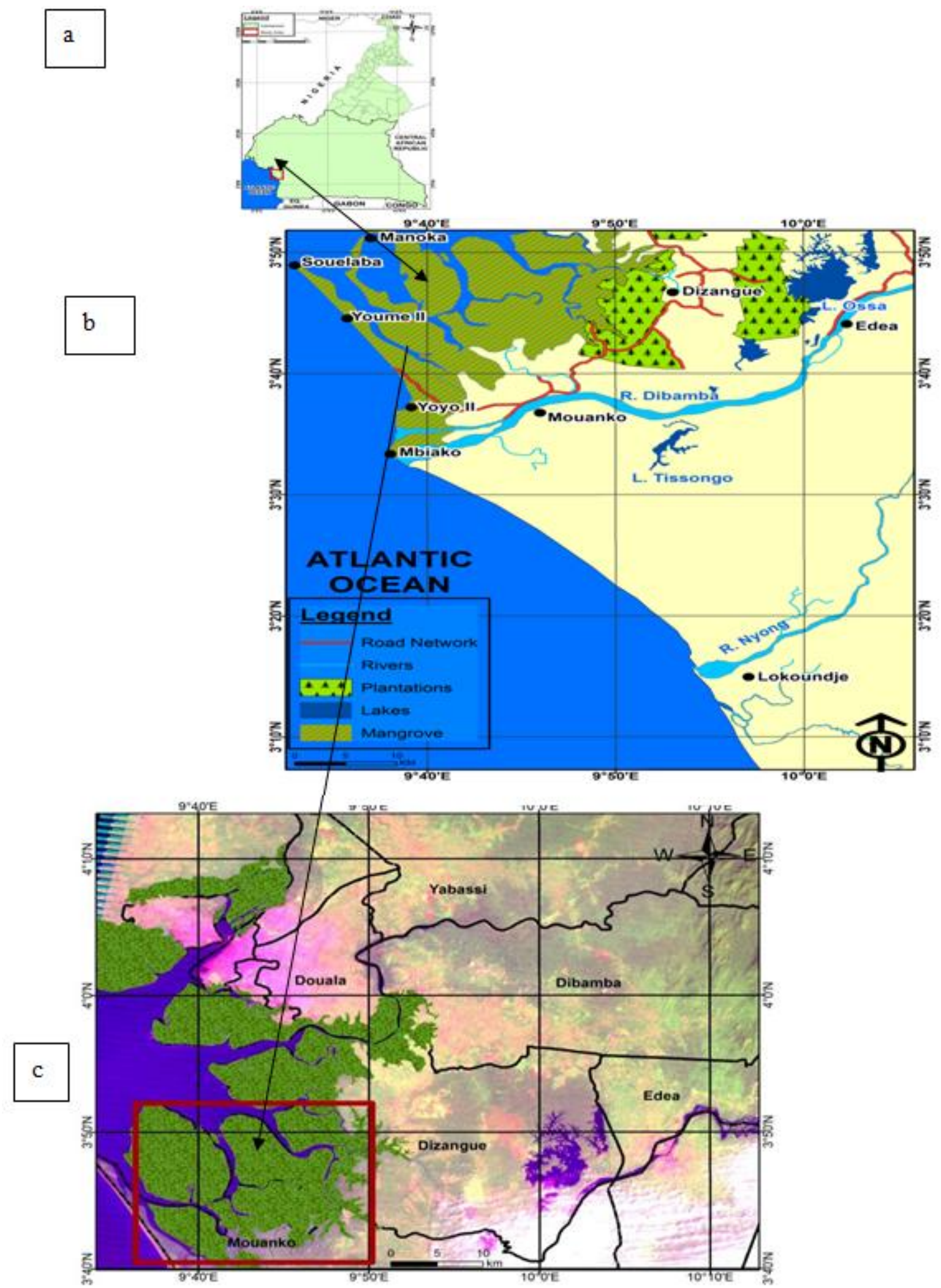

Figure 1: Douala -Edea Reserve (a) Cameroon (b) DEWR (c) study site in red enclosure. (Source: Field survey, 2015 by Wantim, Findi and Longonje )

Volume 5 Issue 8, August 2016 www.ijsr.net 


\section{International Journal of Science and Research (IJSR)}

ISSN (Online): 2319-7064

Index Copernicus Value (2013): 6.14 | Impact Factor (2015): 6.391

\section{Materials and Methods}

\section{Modelling approach}

For the model construction, the ECOPATH II software of Christensen and Pauly (1992) was used, which combines an approach of Polovina (1984) for estimation of biomass and food consumption of the various ecosystem elements (species or species groups) with an approach proposed by Ulanowicz (1986) for analysis of flows between the ecosystem elements and for the calculation of ecosystem indices. In particular, indices used are 'Total System Throughput (T) ', which reflects the size of the system in terms of the sum of flows through all the individual compartments. This index is regarded as a measure of the 'power' generated within the system. 'Ascendency (A)' represents both, size and organization of the flows, while the 'Development Capacity (C)' is the upper limit to ascendency. The contribution of each system component to the overall system's ascendency can be calculated as well and can be regarded as the 'value' of the respective component for the functioning of the entire ecosystem (Ulanowicz, 1997). The degree of a system's realized growth, organization and development can be given by the A/C ratio (Ulanowicz \& Mann, 1981), which tends to be low in systems under stress and high in well organized systems. The latter have the tendency to internalize most of their activity, to become relatively independent of external inflows and outflows and are thus tending towards high temporal stability (Baird \& Ulanowicz, 1993). Other indices used to assess maturity include: (a) trophic transfer efficiencies (supposedly higher in mature systems), (b) the production/respiration ratio $(\mathrm{P} / \mathrm{R}=1$ for mature systems), (c) the degree of energy cycling which increases with maturity (Odum, 1969) as expressed in Finn's cycling index (Finn, 1976) and (iv) 'Overhead ' (O), an indicator of ecosystem stability (Rutledge et al., 1976) representing the potential of the system for further development. These indices have been used by various authors to compare a wide variety of ecosystems of different sizes, geographical location and complexity (e.g. Baird et al., 1991; Ulanowicz \& Wulff, 1991; Christensen \& Pauly, 1993; Wolff, 1994; Wolff et al., 1996; Wolff et al., 1998), and they will be used in our analysis of the Caete' Estuary model. In the ECOPATH model, biomass production of a compartment is balanced by predation, non predation losses, and export. Important input parameters are (for each compartment): biomass $(B)$, production per unit of biomass $(P / B)$, consumption per unit of biomass $(Q / B)$ and export $(E X)$. Ecotrophic efficiency $(E E)$.the fraction of the production used within the system (i.e. entering the other compartments),respiration per unit of biomass $(R / B)$ and gross efficiency $(G E)$ are output parameters that are crucial for examining the modelling results. The modeler defines the model structure by a preypredator matrix indicating for each compartment the fractions of the total consumption contributed by each prey source. The core routine of ECOPATH II basically consists in using a set of simultaneous linear equations (one for each group $i$ in the system), i.e.:

$$
\text { Pi_Bi M2i_Pi (1_EEi)_EXi=0 }
$$

where: $P i=$ the production of $(i)\left(\mathrm{t} / \mathrm{km}^{2} /\right.$ year $) ; B i=$ the biomass of (i) $\left(\mathbf{t} / \mathbf{k m}^{2}\right) ; M 2 i=$ the predation mortality of (i) (yr_1); $E E i=$ the Ecotrophic Efficiency of (i) (fraction of 1);
1_EE $i=$ the ' other sources of mortality' (yr_1); EXi=the export of $(i)\left(\mathrm{t} / \mathrm{km}^{2} /\right.$ year $)$.

Thus, the total production by group ( $i$ ) is balanced by predation from other groups $\left(B i^{*} M 2 i\right)$, by non predation losses $\left(P i\left(1 \_E E i\right)\right)$, e.g. sedimentation, and losses to other systems $(E X)$, e.g. emigration and fishery. Since production is more conveniently estimated from the production/biomass ratio $(P B)$ and the average annual biomass $(B)$, it is expressed as $\left(P i=B i^{*} P B i\right)$. Predation mortality depends on the activity of the predator and can be expressed as the sum of consumption by all predators $(j)$ preying upon group $(i)$, i.e.

$$
\left(B i^{*} M 2 i\right)=j B j^{*} Q B j^{*} D c j i
$$

where: $Q B j=$ consumption/biomass ratio of the predator $j$ $\left(\mathrm{yr}^{1}\right)$ and $D C j i=$ fraction of the prey $(i)$ in the average diet of predator $j$. Equation (1) can be re-expressed as:

$$
B i^{*} P B i^{*} E E i_{-} j B j^{*} Q B j^{*} D C j i\left[E X i^{\prime}=0\right.
$$

Three of the four parameters $B, P B, Q B$ and $E E$ have to be set initially for each group. The remaining parameter is computed by the software. Particularly for some lowertrophic level groups, $E E$ is sometimes changed by the program, even when $P$ or $P B$ are treated as initial unknowns. $Q B$ of a compartment can also be calculated by the model and treated as an unknown in initial parametrization. For further details of the ECOPATH-model structure see Christensen and Pauly (1992).

\section{Selection of model groups (compartments)}

As a first step in model construction is the identification of the model compartments .for this study the model groups was based on either functions or ecological similarities or both, other value driven criteria like commercial status or importance to the local communities and, available information on biomass, turnover $(P / B)$ rates, consumption rates $(Q / B)$, for the species/groups of the system was assembled from literature. Species of similar sizes, diets, consumption rates, mortality and production rates were grouped within a compartment .Table 1 show the main elements of each of the 21 compartments and gives the values that were taken as initial input into the model.

\section{Ecopath input parameters}

The input parameters for each group were: the biomass (B), the production/ biomass ratio $(\mathrm{P} / \mathrm{B})$, the consumption/ biomass ratio $(\mathrm{Q} / \mathrm{B})$ and ecotrophic efficiency $(\mathrm{EE})$. The parameters values were estimated from the field or extracted from literature, either from studies done within a similar mangrove ecosystem (in Central Atlantic region) or on the West Africa continental shelf.

Information to set the diet matrix was taken from literature sources except for crabs groups where stomach content analysis was done. The degree of confidence, that the parameters values were appropriate for Cameroon is expressed through the data pedigree coding option.

In our model, detritus includes associated bacteria. Detritivores are thus considered to mainly feed on bacteria. As the model uses detritus as a non-living group (without production and consumption), bacterial production is not considered in our model. We opted for not using an extra 


\section{International Journal of Science and Research (IJSR) \\ ISSN (Online): 2319-7064 \\ Index Copernicus Value (2013): 6.14 | Impact Factor (2015): 6.391}

bacteria compartment because bacteria would overshadow other trophic flows of the system tremendously (Christensen \& Pauly, 1993). In addition, quantitative data or reasonable estimates on production and biomass of bacteria were not available. A further reason was that most trophic models do not include bacteria, so that a comparison between these and our model becomes easier.

For the biomass $\mathbf{t} / \mathbf{k m}^{\mathbf{2}}$, some of the values of Table 1 had to be derived from own estimates, as published information was not available. (a) The biomass estimates for mangrove was determined from 10 months field observations, allometric relations from sample data with diameter at breast height (dbh) was used (b) Crabs biomasses was our estimate (Longonje, 2008), Biomass for birds was estimated by multiplying the average wet weight of the given species by the average bird abundance (Hoyer and Canfield, 1994). The abundance was obtained from averaging the total species encountered during the survey, while the average wet weight were taken from literature (c) Information on phytoplankton , zooplankton biomass was from literature. A mean biomass conversion ratio of $0.59 \pm 0.08$ reported by Gate et al. (1982) was used to convert dry weight to wet weight.

(d) Fish biomass was estimated by 'sweep area' method used to determine the density of the fish per sqaure kilometers $\left(\mathrm{km}^{2}\right)$ reported by Sherman (1994). With this given a mean weight to be $\mathrm{W}$ and $\mathrm{A}$ to be the area swept, then:

$$
\text { Fish density }=\mathrm{W} / \mathrm{A}\left(\mathrm{kg} / \mathrm{km}^{2}\right)
$$

Where:

$\mathrm{W}=$ the catch weight per week,

$\mathrm{A}=$ average area covered during the fishing trip (approximated to be $60 \%$ of the entire mangrove area $=11.9$ $\left.\mathrm{km}^{2}\right)$.

$\mathrm{Q}=$ efficiency of the net, or catch cofficient representing the amount of the fish caught by the fisher man relatively to the amount that escaped being caught. In this case, $\mathrm{Q}$ was estimated as $60 \%$.

$\mathrm{A}^{1}=$ the area surveyed which equaled the total area (approximately $1306.24 \mathrm{~km}^{2}$ ).

$$
\text { Biomass }=(\mathrm{W} / \mathrm{A}) / \mathrm{QxA}^{1}
$$

The $\mathrm{P} / \mathrm{B}$ ratio of fish is equivalent to total mrtality $(\mathrm{Z})$ which is estimated as the sum of natural mortality (M) and fishing mortality $(\mathrm{F})$ given as:

$$
\mathbf{Z}=\mathbf{F}+\mathbf{M}
$$

Natural mortality was calculated using the Von Bertalanfy growth function (VBGF):

$$
M=K^{0.65} L_{\infty}{ }^{-0.279} T^{0.463}
$$

Where:

$\mathrm{K}=$ the curvature parameter for the VBGF,

$\mathrm{L}=$ the asymptotic length of the fish,

$\mathrm{T}=$ the average environmental temperature estimated at $25.5^{\circ} \mathrm{C}$.

$\mathrm{Q} / \mathrm{B}$ ratio for fish was estimated from empirical relationship proposed by Palomares nd Pauly (1998) to be:

$\begin{array}{llll}\log & \mathrm{Q} / \mathrm{B} & = & \mathbf{7 . 9 6 4 - 0 . 2 0 4}\end{array} \quad \log \mathrm{W}_{\infty}^{-1.965}$

Where by:

$\mathbf{W}_{\infty}$ (or asymptotic weight) $=$ mean weight that the individuals of a population would rech if it were to grow indefinitely.

$\mathrm{T}$ 'is the mean environmental temperature expressed as 1000 $/\left({ }^{\circ} \mathrm{C}+273.15\right)$;

$\mathrm{A}=$ the aspect ratio of the caudial fin and its surface area, $' h$ ' $=$ and ' $d$ 'are dummy variables, indicating herbivores $(\mathrm{h}=1, \mathrm{~d}=0)$ and carnivores $(\mathrm{h}=0, \mathrm{~d}=0)$.

Data was derived by imputing the total length of the species into the fishbase.org and recalculations done so as to reboot the values (Sources: field survey, 2015; fishbase.org.

The value used for of the $P / B$ or $Q / B$ for phytoplankton, zooplankton, birds, Insects, shrimps, crabs, benthos and detritus were from literature.

\section{Balancing the model}

The first step in verifying whether the model output was realistic, was to check if the ecotrophic efficiency $(E E)$ was $<1 \cdot 0$ for all compartments, as values $>1 \cdot 0$ are inconsistent (it is impossible that, under conditions of steady state, more biomass is used than produced by a compartment); if inconsistencies were detected, the $B$ or $P B$ values were adjusted; as a second step, the $G E$ (gross efficiency) and $R / A$ values were checked for their consistency by comparing them with data derived from the field survey carried out by the authors (Longonje,2008 and Findi 2015) and other authors. Some changes of the input values had to be done in order to balance the model. These remained within $15 \%$ of the input value, except for the biomass value for predatory mangroves, that was increased by $10 \%$ and the $P / B$ values of fishes and birds, were increased by $10 \%$.

\section{Results}

Figure 2 shows the compartment model for the balanced Douala-Edea wildlife reserve mangrove ecosystem. The nodes area ligned along the y-axis as a function of the estimated trophic level and the area is proportional of the square root of the biomass (except for the detritus compartment).

Figure 3 presents the modified Lindeman pyramid showing the relative flows through each trophic level. Table 2 summarizes the input values for the final run and those values that were computed by the programme. The diet matrix is given in Table 3 . Table 4 presents the summary statistics, network flow indices and transfer efficiencies calculated for each trophic level. Ninety-percent of the system biomass is comprised by the benthic and $10 \%$ by the pelagic domain. The highest food intake is achieved by the fishes $\left(2.4 \mathrm{t} / \mathrm{km}^{2}\right)$ and birds $\left(1.3 \mathrm{t} / \mathrm{km}^{2}\right)$, followed by crabs $\left(1.09 \mathrm{t} / \mathrm{km}^{2}\right)$ and small benthos $\left(1.07 \mathrm{t} / \mathrm{km}^{2}\right)$ and zooplankton $\left(1.01 \mathrm{t} / \mathrm{km}^{2}\right)$. According to the model results, a significant part of the production of most groups is not directly used in the system (seen by their rather low $E E$-values) and enters the detritus pool, which is used again by many groups (see Table 3). The average transfer efficiency of $13.8 \%$ calculated for the first four trophic levels (Table 4) is within the range $(8-14 \%)$ reported by Christensen and Pauly 


\section{International Journal of Science and Research (IJSR) \\ ISSN (Online): 2319-7064 \\ Index Copernicus Value (2013): 6.14 | Impact Factor (2015): 6.391}

(1993) for 41 aquatic systems and is near the lower end of the range (10-20\%) reported by other authors (Odum, 1971; Barnes \& Hughes, 1988). The largest part of the throughput is achieved from the trophic levels I to II $(56.3 \%)$ and II to III $(25.7 \%)$, with only $9 \%$ remaining for the higher trophic levels.

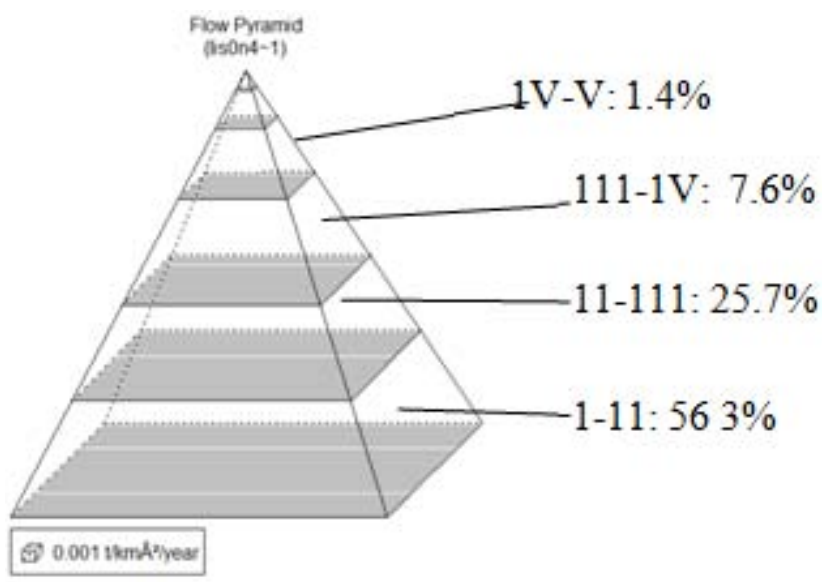

Figure 3: Douala-Edea wildlife reserve mangrove. Modified Lindeman pyramid of flows; the volume of each discrete trophic level is proportional to the throughput (total flow) at that level; the bottom compartment represents herbivory (trophic level II).

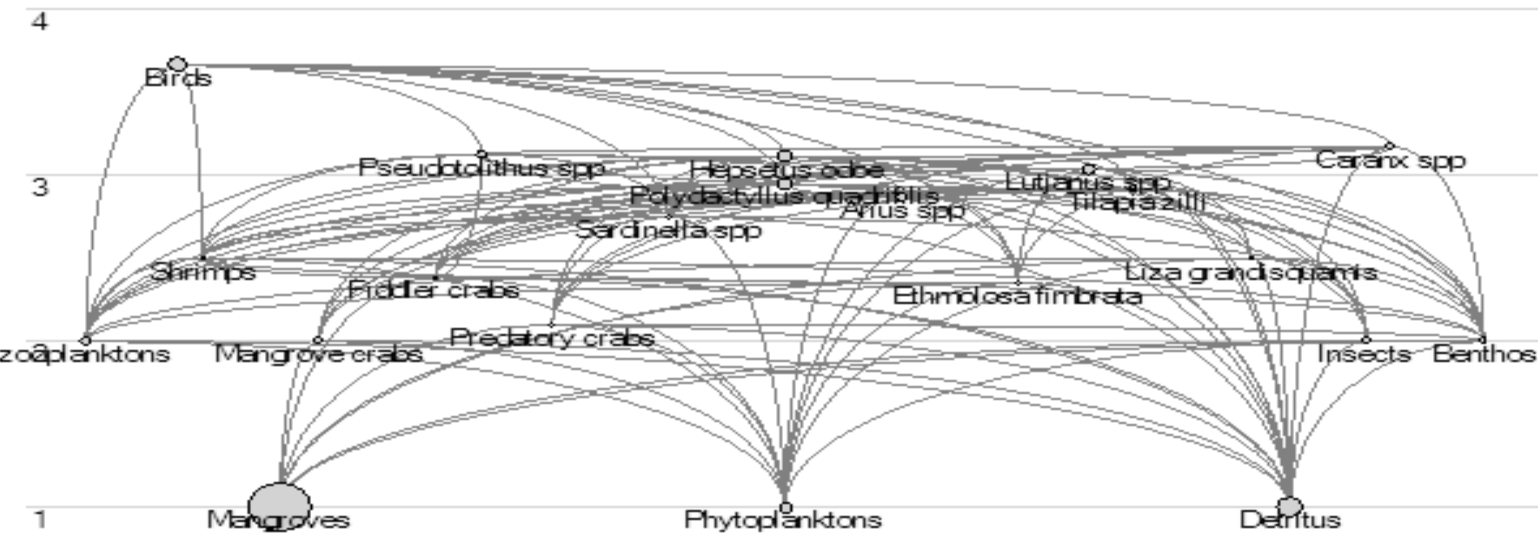

Figure 2: Douala-Edea Wildlife Reserve Mangrove . Trophic model. The box size is proportional to the $\mathrm{t} / \mathrm{km}^{2}$ of the compartment biomass (except for the detritus compartment); all flows are in $\mathrm{t} / \mathrm{km}^{2} \mathrm{yr}_{-} 1$ (wet weight); for further explanation see text.

Table 2: Basic input model estimated output (bold) for the mangrove area

\begin{tabular}{|l|l|l|l|l|l|l|l|l|l|l|}
\hline & Group name & TL & HA & $\mathrm{B}\left(\mathrm{t} / \mathrm{km}^{2}\right)$ & $\mathrm{P} / \mathrm{B}(/$ year $)$ & $\mathrm{Q} / \mathrm{B}(/$ year $)$ & $\mathrm{EE}$ & $\mathrm{P} / \mathrm{Q}$ & OI & $\mathrm{R} / \mathrm{A}$ \\
\hline 1 & Mangroves & 1 & 1 & 0.505 & 54 & & 0.54 & & & \\
\hline 2 & Phytoplanktons & 1 & 1 & 0.29 & 165 & & 0.77 & & & \\
\hline 3 & zooplanktons & 2 & 1 & 0.18 & 50 & 60 & 0.21 & 0.31 & 0.25 & 0.69 \\
\hline 4 & Shrimps & 2.5 & 1 & 0.001 & 3.2 & 32 & 0.88 & 0.1 & & 0.88 \\
\hline 5 & Mangrove crabs & 2 & 1 & 0.005 & 2 & 14 & 0.54 & 0.14 & 0.39 & 0.82 \\
\hline 6 & Fiddler crabs & 2.381 & 1 & 0.001 & 5.5 & 95 & 0.22 & 0.06 & 0.09 & 0.93 \\
\hline 7 & Predatory crabs & 2.1 & 1 & 0.001 & 0.25 & 22 & 0.95 & 0.01 & 0.20 & 0.99 \\
\hline 8 & Birds & 3.66 & 1 & 0.051 & 1.93 & 45 & 0.01 & 0.04 & 0.07 & 0.95 \\
\hline 9 & Pseudotolithus spp & 3.13 & 1 & 0.014 & 0.08 & 3.4 & 0.89 & 0.02 & 0.26 & 0.97 \\
\hline 10 & Sardinella spp & 2.75 & 1 & 0.002 & 0.82 & 21 & 0.95 & 0.04 & 0.27 & 0.95 \\
\hline 11 & Polydactyllus quadrifilis & 2.95 & 1 & 0.035 & 0.25 & 3 & 0.95 & 0.08 & 0.61 & 0.90 \\
\hline 12 & Arius spp & 2.87 & 1 & 0.018 & 0.061 & 6 & 0.03 & 0.01 & 0.44 & 0.99 \\
\hline 13 & Hepsetus odoe & 3.112 & 1 & 0.04 & 2.73 & 2.2 & 0.02 & 1.24 & 0.30 & 0.55 \\
\hline 14 & Ethmolosa fimbrata & 2.35 & 1 & 0.001 & 1.33 & 35.3 & 0.95 & 0.04 & 0.462 & 0.95 \\
\hline 15 & Tilapia zilli & 2.92 & 1 & 0.009 & 2.62 & 113 & 0.05 & 0.02 & 0.42 & 0.97 \\
\hline 16 & Lutjanus spp & 3.04 & 1 & 0.028 & 0.84 & 4.3 & 0.12 & 0.19 & 0.25 & 0.76 \\
\hline 17 & Liza grandisquamis & 2.5 & 1 & 0.001 & 2.03 & 81.6 & 0.1 & 0.03 & 0.28 & 0.97 \\
\hline 18 & Caranx spp & 3.171 & 1 & 0.007 & 0.44 & 5.2 & 0.2 & 0.09 & & 0.89 \\
\hline 19 & Insects & 2 & 1 & 0.0600 & 1.54 & 51 & 0.95 & 0.31 & & 0.62 \\
\hline 20 & Benthos & 2 & 1 & 0.0593 & 1.0 & 10 & 0.95 & 0.6 & 0.29 & 0.25 \\
\hline 21 & Detritus & 1 & 1 & & & & 0.617 & & & \\
\hline
\end{tabular}

\section{Volume 5 Issue 8, August 2016}

www.ijsr.net

Licensed Under Creative Commons Attribution CC BY 


\section{International Journal of Science and Research (IJSR) \\ ISSN (Online): 2319-7064 \\ Index Copernicus Value (2013): 6.14 | Impact Factor (2015): 6.391}

TL: trophic level, B: biomass $\left(\mathrm{t} / \mathrm{km}^{2}\right), \mathbf{P} / \mathbf{B}$ : annual production per biomass ratio, $\mathbf{Q} / \mathbf{B}$ : annual comsumption per biomass ratio, EE: ecotrophic efficiency, $\mathbf{P} / \mathbf{Q}$ : annual production per consumption ratio, OI: omnivory index. R/A: Respiration $/$ assimilation

Table 3: DEWR: Prey-predator matrix used for the ECOPATH-model. Numbers represent weight fractions of food ingested.

\begin{tabular}{|c|c|c|c|c|c|c|c|c|c|c|c|c|c|c|c|c|c|c|c|}
\hline & & 3 & 4 & 5 & 6 & 7 & 8 & 9 & 10 & 11 & 12 & 13 & 14 & 15 & 16 & 17 & 18 & 19 & 20 \\
\hline 1 & Mangrove & - & - & 0.6 & 0.5 & 0.7 & - & - & - & & & - & 0.2 & - & - & 0.1 & - & 0.1 & $0-.8$ \\
\hline 2 & phytoplankton & 0.8 & 0.1 & 0.1 & 0.1 & 0.1 & - & - & 0.1 & & 0.1 & - & 0.3 & 0.1 & 0.1 & 0.2 & - & 0.5 & - \\
\hline 3 & Zooplanktons & - & 0.4 & - & - & - & 0.05 & 0.4 & 0.4 & 0.2 & 0.1 & 0.1 & 0.2 & 0.1 & 0.2 & 0.3 & - & - & - \\
\hline 4 & shrimps & - & - & - & 0.05 & - & 0.05 & 0.1 & 0.1 & 0.1 & 0.05 & 0.1 & 0.1 & 0.1 & - & - & - & - & - \\
\hline 5 & Mangrove crabs & - & - & - & - & - & - & - & - & 0.05 & 0.1 & 0.05 & - & 0.05 & - & - & 0.1 & - & - \\
\hline 6 & Fiddler crabs & - & - & - & - & & - & - & - & 0.1 & 0.05 & 0.05 & - & 0.05 & - & - & 0.1 & - & - \\
\hline 7 & Predatory crabs & - & - & & - & - & - & - & - & 0.05 & 0.05 & 0.05 & - & 0.05 & - & - & 0.1 & - & \\
\hline 8 & Birds & & - & - & - & - & - & - & - & - & - & - & - & - & - & - & - & - & - \\
\hline 9 & Pseudotolithus spp & - & - & - & 0.05 & - & 0.1 & - & - & - & 0.05 & 0.05 & - & 0.05 & - & & 0.1 & - & - \\
\hline 10 & Sardinella & - & - & - & - & - & 0.1 & 0.1 & - & 0.05 & 0.05 & 0.05 & - & 0.05 & 0.05 & - & 0.1 & - & - \\
\hline 11 & Polydactyllus quadrifills & - & - & - & - & - & 0.1 & - & - & & 0,05 & & - & 0.05 & - & - & & - & - \\
\hline 12 & Arius spp & - & - & - & - & - & - & - & - & - & -- & 0.05 & - & - & - & - & & & - \\
\hline 13 & Hepsetus odoe & - & - & - & - & - & 0.1 & - & & - & - & - & - & - & 0.05 & - & & - & - \\
\hline 14 & Ethmolosa fimbriata & - & -- & & - & - & 0.1 & - & - & 0.05 & - & 0.05 & - & - & 0.05 & - & 0.1 & - & \\
\hline 15 & Tilapia zilli & - & - & - & -- & - & 0.1 & - & - & & & & - & - & 0.05 & & & - & - \\
\hline 16 & Lutjanus spp & - & - & - & - & - & - & - & - & & 0.05 & & -- & - & - & - & - & - & - \\
\hline 17 & Liza grandisquamis & - & - & - & - & -- & - & - & - & & 0.05 & 0.05 & - & - & 0.05 & - & - & - & - \\
\hline 18 & Caranx spp & & - & - & - & - & 0.1 & - & - & & - & 0.05 & - & - & 0.05 & - & - & - & - \\
\hline 19 & Insects & - & - & -- & - & - & 0.1 & 0.1 & - & & - & 0.05 & - & 0.1 & & 0.1 & - & - & - \\
\hline 20 & Benthos & - & 0.1 & - & 0.2 & 0.1 & 0.1 & 0.3 & 0.2 & 0.2 & - & 0.1 & - & 0.1 & 0.3 & 0.1 & 0.3 & - & - \\
\hline \multirow[t]{2}{*}{21} & Detritus & 0.2 & 0.4 & 0.3 & 0.1 & 0.1 & - & - & 0.2 & 0.2 & 0.3 & 0.2 & 0.2 & 0.2 & 0.1 & 0.2 & 0.1 & 0.4 & 0.2 \\
\hline & TOTAL & 1 & 1 & 1 & 1 & 1 & 1 & 1 & 1 & 1 & 1 & 1 & & 1 & 1 & 1 & 1 & 1 & 1 \\
\hline
\end{tabular}

Literature sources : 3 Wolf et al. (1998); 4Mendy (2004); 5, 6, 7 own estimates, 8Vakily and Cham (2003); 9 Samb and Mendy (2004); 10 Diallo et al. (2004); 11 Samb (2004); 12. Ben-Tuvia et al. (1986); 13, 14 Diallo et al. (2004) 15 Mendy (2004) with no units since it's in proportion.

Table 4: DEWR mangrove: Summary statistics of the model, network flow indices and ecotrophic efficiencies by each trophic level (\%). For further explanations see text and Christensen and Pauly (1992)

\begin{tabular}{|c|c|c|}
\hline Parameter & Value & Units \\
\hline Sum of all consumption & 155.37 & $\mathrm{t} / \mathrm{km}^{2} /$ year \\
\hline Sum of all exports & 22.74 & $\mathrm{t} / \mathrm{km}^{2} /$ year \\
\hline Sum of all respiratory flows & 56.43 & $\mathrm{t} / \mathrm{km}^{2} /$ year \\
\hline Sum of all flows into detritus & 59.48 & $\mathrm{t} / \mathrm{km}^{2} /$ year \\
\hline Total system throughput (T) & 400.54 & $\mathrm{t} / \mathrm{km}^{2} /$ year \\
\hline Sum of all production & 148.75 & $\mathrm{t} / \mathrm{km}^{2} /$ year \\
\hline Calculated total net primary production & 75.12 & $\mathrm{t} / \mathrm{km}^{2} /$ year \\
\hline Total primary production/total respiration & 1.3 & \\
\hline Net system production & 18.69 & $\mathrm{t} / \mathrm{km}^{2} /$ year \\
\hline Total primary production/total biomass & 11.84 & $\mathrm{t} / \mathrm{km}^{2} /$ year \\
\hline Total biomass/total throughput & 0.0216 & $/$ year \\
\hline Total biomass (excluding detritus) & 6.343 & $\mathrm{t} / \mathrm{km}$ \\
\hline Connectance Index & 0.298 & \\
\hline System Omnivory Index & 0.174 & \\
\hline Ecopath pedigree index & 0.489 & \\
\hline Measure of fit $\mathrm{t}$ & 2.365 & \\
\hline
\end{tabular}

$\begin{array}{lrc}\text { Flowbit } & (\%) & \text { Unit } \\ \text { Ascendancy } & 473.8 & 32 \cdot 5 \\ \text { Overhead } & 983.9 & 67.5 \\ \text { Capacity } & 1458.2 & 100\end{array}$

Throughput cycled (excl. detritus) $19 \cdot 9 \mathrm{t} / \mathrm{km}^{2} /$ year Finn's cycling index 4.98 (\% of total throughput) Mean length of pathways 3.03 food chain steps
Transfer efficiencies (TE) (\%) by trophic level I II III IV V V1 V11

$=4.545 .617 .49 .25 .74,7$

Proportion of flows originating from detritus: $0 \cdot 23$

\section{Discussion}

\section{Evaluation of the compartment parameters}

The parameter estimates of the programme appear reasonable. The Respiration / assimilation $(R / A)$ for the fishes and crabs compartments $(0.99$ and around 0.80$)$ are within the range reported by Koch (1999), except for the very low value of 0.55 for Hepsetus odoe .

The lowest $\mathrm{R} / A$ values are those for zooplankton, benthos and insect as can be expected as they do not respire most of the assimilated food and production is rather high.

\section{Ecosystem flow characteristics, summary statistics}

The model estimate of total system throughput (T), i.e. the sum of all flows (consumption, exports, respiratory flows and flows into detritus) of $4005.4 \mathrm{t} / \mathrm{km}^{2} /$ year (Table 4) appears high when compared to other tropical coastal systems reported in the literature. Wolff et al. (1996) estimated a $T$-value of $1404 \mathrm{t} / \mathrm{km}^{2} /$ year for a tropical Pacific fjord (Golfo Dulce, Costa Rica), Arreguin-Sa'nchez et al. (1993) of $2049 \mathrm{t} / \mathrm{km}^{2} /$ year for Campeche bank (Mexico), Silvestre et al. (1993) of $2934 \mathrm{t} / \mathrm{km}^{2} /$ year for the South China Sea, Wolff et al. (1998) of $3049 \mathrm{t} / \mathrm{km}^{2} /$ year for the Golfo de Nicoya ecosystem (Costa Rica). Higher values are given by Mendoza (1993) for the Venezuelan shelf ecosystem (7621 t/ $\mathrm{km}^{2} /$ year ) and Chavez et al. (1993) for Celestun Lagoon, southern Gulf of Mexico (8969 t/ $\mathrm{km}^{2} /$ year ). The latter authors report as we do in our model high biomass and production values for benthic producers, 


\section{International Journal of Science and Research (IJSR) \\ ISSN (Online): 2319-7064}

Index Copernicus Value (2013): 6.14 | Impact Factor (2015): 6.391

including mangroves, which is probably the reason for the high $T$-values in both models. These throughput values are still low, however, when compared to upwelling systems, for which $T$-values $>20000 \mathrm{t} / \mathrm{km}^{2} /$ year have been reported (Jarre et al., 1991; Wolff, 1994). The system primary production/respiration $(P / R)$ ratio calculated by the model $(1 \cdot 3)$ (Table 4) is indicative for a rather undeveloped system (Christensen \& Pauly, 1993), confirmed by the low values for the system ascendency $(A)$ and average transfer efficiency $(T E)$ of $32.5 \%$ and $7 \cdot 8 \%$ respectively. Both, $A$ and $T E$ values are at the lower end of the ranges for the 21 trophic models reported in Christensen and Pauly (1993). Total system biomass $\left(6.4 \mathrm{t} / \mathrm{km}^{2} /\right.$ year $)$ is extremely high due to the fact that the mangroves were included as a system compartment. If mangroves were not considered for the biomass estimate, the resulting $0.55 \mathrm{t} / \mathrm{km}^{2} /$ year figure fits well within the range of other tropical shelf systems. A system picture emerges in which the biomass and energy fluxes are concentrated in the benthic domain within the mangrove forest, but where a certain degree of benthopelagic coupling also takes place. In trying to valuate the different model compartments in terms of their contribution to the overall system function, Ulanowicz (1997) proposes to calculate and use as a measure the relative ascendancy of each group. In our model detritus (including associated bacteria) contributes $34 \%$, mangroves $19 \%$, fiddler crabs $13 \%$, phytoplankton and microphytobenthos $10 \%$, mangrove crabs $10 \%$, and the remaining 14 compartments $14 \%$ to the overall system's ascendency. This confirms the great importance of the forest compartments (mangrove, detritus, detritivores, herbivores) compared to the aquatic compartments of the system studied. The fisheries mean trophic level $(2 \cdot 1)$ is very low and reflects the fact that the most important resource besides the mangroves, is the mangrove crab which, as a herbivore, feeds on the first trophic level. The high gross efficiency of the total harvest $(8 \cdot 6 \%)$ underlines

this and clearly shows that a very large part of the system's benthic production is harvested. If mangroves were excluded from this calculation, the resulting fishery efficiency is still higher $(0.51 \%)$ than in most other models reported by Christensen and Pauly (1993). Even for the heavily overfished Golfo de Nicoya (Costa Rica), Wolff et al. (1998) report a lower value $(0 \cdot 3 \%)$. Fishery efficiencies like our estimate or even higher are reported for systems exposed to intensive milkfish cultivation in the Philippines (DeLos Reyes, 1993), a heavily exploited lake in Southern India (Aravindan, 1993) and upwelling systems (Jarre et al., 1991; Wolff, 1994). Here, the main fishery targets also feed low in the food chain, similar to the mangrove crabs in the Caete' Estuary. If compared to a trophic model of another mangrove fringed estuary (Golfo de Nicoya, Costa Rica) (Wolff et al., 1998), an important feature of the estuary ecosystem becomes evident. While in the Golfo de Nicoya, as in many estuarine systems, most energy transfer seems to occur within the water column and/or through benthopelagic coupling, within the Caete' ecosystem most energy is cycled within the mangrove forest. This seems due to the fact that the largest part of the forest is inundated each fortnight only, allowing for a tight coupling of mangroves, mangrove crabs, the microbial loop and fiddler crabs. The primary energy of the mangroves is thus cycled in form of a positive feedback-loop: the mangrove crabs benefit from the leaf litter production, of which only a small fraction is assimilated (Koch, 1999), while the remaining part fuels the microbial loop in the detritus compartment, enhancing the food supply for the deposit feeding fiddler crabs. The trees in turn benefit from the activity of the crabs which (a) retain nutrients and energy by consuming most of the leaf litter, (b) increase leaf degradation and nutrient remineralization by almost two orders of magnitude by shredding the leaves (Robertson \& Blaber, 1992) and (c) improve soil oxygenation by their burrowing and feeding activities which appears to stimulate mangrove production (Smith III et al., 1991). Local fishermen report much higher fish catches during favorable seasons which they therefore call (season of the fish). It appears that the increased input of organic matter into the estuary is the cause for the observed high mangrove biomass. If the mangrove plants were depleted by the logging, this will disrupt food supply and production in the aquatic food web. Within the forest, however, the feed back cycle would be disturbed leading finally to a decrease in ecosystem productivity. The populations of crabs (and with it their predators) would also be negatively affected because of the decreased food supply. Local sea-level rise due to global warming might have similar consequences as the inundation frequency of the mangrove forest and the export of organic material to the estuary.

\section{Acknowledgements}

We thank all workers of the Cameroon Wildlife Conservation-Project that contributed to this paper. We also thank Dr. Wantim Mabel for providing technical assistance on GIS and remote sensing issues related to the study.

\section{References}

[1] Arreguin-Sanchez, F., Seijo, J. C. \& Valero-Pacheco, E. 1993 An application of ECOPATH II to the north continental shelf of Yuacatan, Mexico. In Trophic Models of Aquatic Ecosystems (Christensen, V. \& Pauly. D., eds). ICLARM Conference Proceedings, No. 26, pp. 269-278.

[2] Baird, D., McGlade, J. M. \& Ulanowicz, R. E. 1991 The comparative ecology of six marine ecosystems. Philosophical Transactions of the Royal Society of London B 333, 15-29.

[3] Baird, D. \& Ulanowicz, R. E. 1993 Comparative study on the trophic structure, cycling and ecosystem properties of four tidal estuaries. Marine Ecolology Progress Series 99, 221-237.

[4] Ben-Tuvia, A. and R. McKay. 1986. Fishes of the north-eastern Atlantic and the Mediterranean. UNESCO, Paris. 2: 858-864pp

[5] Christensen, V. \& Pauly, D. 1992 ECOPATH II-a software of balancing steady state ecosystem models and calculating network characteristics. Ecological Modelling 61, 169-185.

[6] Christensen, V. \& Pauly, D. (eds) 1993 Trophic Models of Aquatic Ecosystems. ICLARM Conference Proceedings, no. 26, 390 pp. Clay, R. E. \& Andersen, A. N. 1996 Ant fauna of a mangrove community in the Australian Seasonal Tropics, with particular reference to zonation. Australian Journal of Zoology 44, 521533. 


\section{International Journal of Science and Research (IJSR) ISSN (Online): 2319-7064 \\ Index Copernicus Value (2013): 6.14 | Impact Factor (2015): 6.391}

[7] CWCS , 2008. Cameroon Wildlife Conservation Society Douala-Edea Forest Project: Report of activities, Mounko, Cameroon.

[8] DeLos Reyes, M. R. 1993 Fish pen culture and its impact on the ecosystem of Laguna de Bay, Philippines. In Trophic Models of Aquatic Ecosystems (Christensen, V. \& Pauly. D., eds). ICLARM Conference proceedings, No. 26, pp. 74-84.

[9] Din N, Saenger P, Priso RJ, Dibong DS, Blasco F 2008: Logging activities in mangrove forests: A case study of Douala Cameroon. AJEScience Technol, 2(2):22-30.

[10] Diallo, I., I. Cissé, and A. Bah. 2004. Modèle trophique du système système côtier du plateau continental Guinéen. 113-123pp .In: Palomares, M.L.D., Pauly, D. (eds.) West African marine ecosystems: models and fisheries impacts. Fisheries Centre Research.

[11] Feka, N.Z., Chuyong, G.B. and Ajonina, G.N. (2009). Sustainable utilization of mangroves using improved fish smoking systems: A management perspective from the Douala-Edea Wildlife Reserve, Cameroon. Tropical Conservation Science 4:450-468.

[12] Findi, E. (2015) Mangrove dynamics and ecosystem health in Douala-Edea reserve, Cameroon. Msc Thesis, University Buea

[13] Gates, M., A. Rogerson, and J. Berger. 1982. Dry and wet weight biomass conversion constant for tetrehymena elliotti ( Ciliophora, Protozoa) . Oecologia 55: $145-148$.

[14] Koch, V. 1999 Epibenthic Production and Energy Flow in the Caete'Mangrove Estuary, North Brazil. $\mathrm{Ph} . \mathrm{D}$. Thesis at the University ofBremen, Germany. ZMT contribution No. 6.

[15] Longonje, S. (2008) Distribution, Diversity and Abundance of Crabs in Cameroon. Mangroves. PhD Thesis, University of York, York.

[16] Mendy, A. N. 2004. A trophic model of the Gambian continental shelf in 1986. 81-88pp. In: Palomares, M.L.D., Pauly, D.(eds.) West African marine ecosystems: models and fisheries impacts. Fisheries Centre Research Reports 12(7). Fisheries Centre, UBC, Vancouver.

[17] Nfotabong AA, Din N, Longonje SN, Koedam N, Dahdouh-Guebas F. 2009. Commercial activities and subsistence utilization of mangrove forests around the Wouri estuary and the Douala-Edea reserve (Cameroon). J, Ethnobio Ethnomed. 5:35. doi: 10.1186/1746-4269-5-35.

[18] Odum, E. P. 1969 The strategy of ecosystem development. Science 104, 262-270.

[19] Polovina, J. J. 1984 Model of a coral reef ecosystem I. The ECOPATH model and its application to French Frigate Shoals. Coral Reefs 3, 1-11.

[20] Rutledge, R. W., Bacore, B. L. \& Mulholland, R. J. 1976 Ecological stability: an information theory viewpoint. Journal of Theoretical Biology 57, 355371.

[21] Samb, B. 2004. L'écosystème sénégambien . In: Palomares, M.L.D., Pauly, D. (eds.).West African marine ecosystems: models and fisheries impacts. Fisheries Centre Research Reports 12(7). Fisheries Centre, UBC,Vancouver.
[22] Silvestre, G., Selvanathan, S. \& Salleh, A. H. M. 1993 Preliminary trophic model of the coastal fisheries resources of Brunei Darussalam, South China Sea. In Trophic Models of Aquatic Ecosystems (Christensen, V. \& Pauly, D., eds). ICLARM Conference Proceedings, No. 26, pp. 300-306.

[23] Ulanowicz, R. E. 1986 Growth and Development: Ecosystems Phenomenology. Springer Verlag, New York, $203 \mathrm{pp}$.

[24] Ulanowicz, R. E. 1997 Ecology, the Ascendent Perspective. Complexity in Ecological Systems Series, Columbia University Press, NewYork, 201 pp.

[25] Ulanowicz, R. E. \& Mann, K. H. 1981 Ecosystems under stress. In Mathematical Models in Biological Oceanography (Platt, T., Mann, K. H. \& Ulanowicz, R. E., eds). The UNESCO Press, Paris, pp. 133-137.

[26] Ulanowicz, R. E. \& Wulff, F. 1991 Comparative ecosystem structures: The Chesapeake Bay and the Baltic Sea. In Comparative Analysis of Ecosystems. Patterns, Mechanisms and Theories (Cole, J., Lovett, G. \& Findlay. S., eds). Springer-Verlag, Heidelberg, pp. 140-160.

[27] Vakily, J.M. and A. Cham. 2003. Growth, feeding and reproduction of the West African Ilisha, Ilisha africana off Sierra Leone. p. 46-57. In: M.L.D. Palomares, B. Samb, T. Diouf, J.M. Vakily and D. Pauly (eds.). Fish biodiversity: local studies as basis for global inferences. ACP-EU Fish Research Report. 14. 281pp

[28] Wolff, M. 1994 A trophic model for Tongoy bay-A system exposed to suspended scallop culture (Northern Chile). Journal of Experimental Marine Biology and Ecology 182, 149-168.

[29] Wolff, M., Hartmann, H. \& Koch, V. 1996 A trophic model for Golfo Dulce, a fjord-like tropical embayment, Costa Rica. Revista de Biologia Tropical 44 (Suppl 3), 215-231.

[30] Wolff,M., Koch, V., Chavarria, J. B. \& Vargas, J. A. 1998 A trophic flow model of the Golfo de Nicoya, Costa Rica. Revista de Biologia Tropical 46 (Suppl 6), 63-79. 